\title{
Cell Microencapsulation and Cryopreservation with Low Molecular Weight Hyaluronan and Dimethyl Sulfoxide \\ H. Gurruchaga ${ }^{1,2}$, L. Saenz del Burgo ${ }^{1,2}$, G. Orive ${ }^{1,2,3}$, R. M. Hernandez ${ }^{1,2}$, J. Ciriza ${ }^{1,2, *}$ and J. L. Pedraz ${ }^{1,2, *}$
}

\begin{abstract}
${ }^{1}$ NanoBioCel Group, Laboratory of Pharmaceutics, School of Pharmacy, University of the Basque Country (UPV/EHU), Paseo de la Universidad 7, 01006 Vitoria-Gasteiz, Spain; ${ }^{2}$ Biomedical Research Networking Center in Bioengineering, Biomaterials and Nanomedicine (CIBER-BBN), Vitoria-Gasteiz, Spain; ${ }^{3}$ University Institute for Regenerative Medicine and Oral Implantology-UIRMI (UPV/EHU-Fundación Eduardo Anitua), Vitoria, Spain; BTI Biotechnology Institute, Vitoria, Spain *For correspondence: jesus.ciriza@ehu.eus; joseluis.pedraz@ehu.eus
\end{abstract}

[Abstract] Cryopreservation is commonly used for the storage of cells, tissues, organs or 3D cell-based products using ultra-low temperatures, which involves the immersion in liquid nitrogen for their long-term preservation. The cryopreservation of several microencapsulated cells is usually performed by the slow freezing with the dimethyl sulfoxide (DMSO) as a cryoprotectant agent (CPA). In this study, we cryopreserved several microencapsulated cells with the natural, non-toxic low molecular-weight hyaluronan (LMW-HA) at $5 \%$ and DMSO $10 \%$ solution assessing cell viability and metabolic activity after thawing. The cryopreservation of microencapsulated D1 mesenchymal stem cells (D1MSC) and murine myoblast cells (C2C12) with the LMW-HA 5\% presented similar outcomes after thawing compared to the DMSO solution, showing the low molecular weight hyaluronan as a natural, non-toxic CPA that can be used preventing the DMSO related adverse effects after the implantation of the cryopreserved cell-based products.

Keywords: Cryoprotectant agent, Slow freezing, Hyaluronan, Dimethylsulfoxide, Cell microencapsulation

[Background] Cell microencapsulation is extensively used to enclose cells allowing the exchange of nutrients between the environment and the core of the microcapsule containing the cells. In vivo, microcapsules protect the cells from the immune system while allowing the release of therapeutic molecules by the entrapped cells (Orive et al., 2014). Consequently, these advantages have promoted the development and employment of cell encapsulation in organ replacement, tissue engineering and regenerative medicine as drug and cell delivery therapies (Gurruchaga et al., 2015b). Nowadays the storage of microencapsulated cells is performed by slow freezing using a linear cooling rate (-0.3-1 ${ }^{\circ} \mathrm{C} / \mathrm{min}$ ) (Murua et al., 2009). Different cryoprotectant agents (CPAs) have been used for their cryopreservation being dimethylsulfoxide (DMSO) the most used with good results in a wide range of microencapsulated cells (Massie et al., 2011; Gurruchaga et al., 2015a; Gryshkov et al., 2015). However, DMSO has been related to several adverse reactions after the implantation of cryopreserved cell-based products (Shu et al., 2014; Ruiz-Delgado et al., 2009) such as cardiac arrhythmia, cardiac 
arrest, tonic-clonic seizure or diarrhea among others, being other alternative CPAs investigated to overcome the DMSO's drawback (Mantri et al., 2015). In this context, low molecular weight hyaluronan (LMW-HA), a natural non-toxic CPA, has demonstrated cryoprotective effects in the cryopreservation of several cell types (Hutson et al., 2009; Ujihira et al., 2010; Iwama et al., 2014). Therefore, in this study, we have determined the cryoprotective effect of LMW-HA $5 \%$ for the cryopreservation of D1 mesenchymal stem cells (D1MSC) and murine C2C12 myoblast (C2C12) compared to DMSO 10\% in each cell medium. LMW-HA $5 \%$ preserved the metabolic activity and cells viability similarly to DMSO containing solutions after thawing, showing the potential of LMW-HA as a CPAs. Although the use of LMW-HA as a CPA has been investigated in microencapsulated cells, it may represent an alternative CPA in the cryopreservation of other 3D cell-based products avoiding the use of DMSO.

\section{Materials and Reagents}

\section{A. Materials}

1. Pipette tips (Sharlab, catalog number: 00PC1000-1)

2. $1.5 \mathrm{ml}$ Eppendorf tubes (Sharlab, catalog number: 027200400P)

3. T-175 flask $\left(175 \mathrm{~cm}^{2}\right)$ (Corning, catalog number: 431466)

4. T-75 flask $\left(75 \mathrm{~cm}^{2}\right)$ (Corning, catalog number: $431464 \mathrm{U}$ )

5. $15 \mathrm{ml}$ centrifuges tubes (Corning, catalog number: 430791)

6. $50 \mathrm{ml}$ centrifuges tubes (Corning, catalog number: 430828)

7. 96-well plates (Corning, catalog number: 353072 )

8. 24-well plates (Corning, catalog number: 3524 )

9. $5 \mathrm{ml}$ polystyrene round bottom tubes (Corning, catalog number: 352052 )

10. Cryovials (Corning, catalog number: 430489)

11. $0.22 \mu \mathrm{m}$ syringe filter NML plus (Minisart, catalog number: 17823)

12. Stericup ${ }^{\circledR}$ (Merk Millipore, model: SCVPU02RE)

13. Cell strainer 40 and $100 \mu \mathrm{m}$ (Corning, catalog number: 352360 )

14. Luer $10 \mathrm{ml}$ syringe (Braun, catalog number: 4606108V)

B. Cells

1. D1 mesenchymal stem cells (D1MSC) (ATCC, catalog number: CRL12424)

2. Murine myoblast cells (C2C12) (ATCC, catalog number: CRL1772)

C. Reagents

1. Liquid nitrogen (Air liquid)

2. Reverse osmosis water (Merck Milli Q system, catalog number: 7003/7005)

3. Dubelcco's Phosphate Buffered Saline (DPBS) (GIBCO, catalog number: D8537)

4. DPBS containing $\mathrm{Ca}^{2+}$ and $\mathrm{Mg}^{2+}$ (Lonza, catalog number: 17-512F)

5. Trypsin $0.25 \%$ (GIBCO, catalog number: 25200056 ) 
6. Mannitol (Sigma, catalog number: M4125)

7. Calcium chloride (Sigma, catalog number: C4901)

8. Ultra-pure low-viscosity and high glucuronic acid alginate (LVG) (Novamatrix, catalog number: BP-1410-19)

9. Sodium citrate (tri-Sodium Citrate 2-hydrate) (Panreac Application, catalog number: 141655.1211)

10. D1MSCs culture medium (ATCC, catalog number: DMEM 30-2002)

11. C2C12 culture medium (Gibco, catalog number: DMEM 11960)

12. Fetal bovine serum (FBS) (Gibco, catalog number: 42G9273K)

13. Antibiotic/antimycotic (Gibco, catalog number: 15140-122)

14. Dimethyl sulfoxide (DMSO) (ATCC, catalog number: A503039)

15. Low molecular-weight hyaluronan 30-50 kD (LMW-HA) (Contipro, catalog number: 9067-32-7)

16. Cell counting kit-8 (Sigma, catalog number: 96992-500TESTS-F)

17. LIVE/DEAD ${ }^{\text {TM }}$ Viability/Cytotoxicity kit (488/570) (Invitrogen, catalog number: L3324)

18. Annexin V-FITC Apoptosis Detection Kit (Sigma, catalog number: APOAF-50TST)

19. D1MSC complete medium (see Recipes)

20. C2C12 complete medium (see Recipes)

21. DMSO 10\% CPA solution (see Recipes)

22. LMW-HA 5\% CPA solution (see Recipes)

23. $1 \%$ mannitol (see Recipes)

24. $55 \mathrm{mM}$ calcium chloride (see Recipes)

25. $1 \%$ sodium citrate (see Recipes)

26. $1.5 \%$ alginate LVG (NovaMatrix) (see Recipes)

27. Calcein/ethidium staining solution (for microscopy) (see Recipes)

28. Calcein/ethidium staining solution (for flow cytometry) (see Recipes)

\section{Equipment}

1. Sterile spatula (Sharlbab, catalog number: $3100000 \mathrm{BOC}$ )

2. Pipettes $2-20 \mu \mathrm{l}, 20-200 \mu \mathrm{l}, 100-1,000 \mu \mathrm{l}$ (Eppendorf, catalog number: 4924000916)

3. CoolCell ${ }^{\circledR}$ Cell Freezing Containers (Alcohol-free controlled-rate $-1{ }^{\circ} \mathrm{C} / \mathrm{min}$ cell freezing containers) (Corning Biocision, catalog number: BCS-405)

4. $-80^{\circ} \mathrm{C}$ freezer (Thermo Fisher, catalog number: TSX40086A)

5. TC20 ${ }^{\mathrm{TM}}$ automated cell counter (Bio-Rad, catalog number: 145-0101)

6. Water bath at $37^{\circ} \mathrm{C}$ (Memmert, catalog number: WNB 45)

7. Laminar flow hood (Burdinola, catalog number: $\mathrm{AH}-100$ )

8. Centrifuge Mixtasel-BL (Selecta, catalog number: 7002575)

9. $\mathrm{CO}_{2}$ incubator (Sanyo, catalog number: $\mathrm{MCO}-20 \mathrm{AIC}$ )

10. Fridge (Liebherr, catalog number: 12084121) 
11. Autoclave Autester ST (Selecta, catalog number: 4002517)

12. Microscope (Nikon TMS microscope, catalog number: 310450)

13. Liquid nitrogen tanks (Air liquid, catalog number: ARPEGE40-L-102)

14. Vacuum pump (Millipore, catalog number: XF54 23050)

15. FACS Calibur flow cytometer ${ }^{\mathrm{TM}}$ [Becton Dickinson (BD)]

16. Infinite ${ }^{\circledR}$ M200 microplate reader (Tecan, model: Infinite ${ }^{\circledR}$ M200)

17. Encapsulation process materials (Unless another company is indicated, all components are part of the system and purchased as a unit from Nisco encapsulation unit Var V1, catalog number: LIN-0203) (All materials are sterilized previously to cell microencapsulation):
a. Electrostatic droplet generator
b. Beaker ( $80 \mathrm{~mm}$ diameter, $40 \mathrm{~mm}$ height and $80 \mathrm{ml}$ volume)
c. Stirring
d. Needle
e. Needle holder
f. Peristaltic pump
g. Silicone tube
h. Stainless steel stick
i. Silicone tube
j. Luer $10 \mathrm{ml}$ syringe (Braun, catalog number: 4606108V)

\section{Software}

1. Microsoft Office Excel (Microsoft)

2. FlowJo $^{\circledR}$ V10 (Flowjo, LLC)

3. SPSS statistics 22 (IBM)

4. Eclipse Net software, version 1.20.0 (Nikon)

\section{Procedure}

A. Thawing and cell culture conditions

1. When required, recover the D1 mesenchymal stem cells (D1MSC) and murine myoblast cells (C2C12) by rapidly thawing cryovials in a $37^{\circ} \mathrm{C}$ water bath until no ice is observed (4-5 min).

2. Next, take cryovials into a laminar flow hood, transfer each cell suspension into a $50 \mathrm{ml}$ conical centrifuge tube and dilute samples with $10 \mathrm{ml}$ of complete culture medium.

3. Spin the cell suspensions, remove the supernatant and resuspend each cell pellet with $20 \mathrm{ml}$ of culture medium.

4. Then, place each cell suspension separately into $\mathrm{T}-175$ flasks and incubate them at $37^{\circ} \mathrm{C}$ in a humidified $5 \% \mathrm{CO}_{2} / 95 \%$ air atmosphere. 
5. Cultivate the cells in as many T-175 flasks as needed depending on the cell density that will be used for encapsulation, and the final volume of the batch that will be fabricated. Cells should be passaged when cell confluency is around $70 \%$ (every $2-3$ days if $1 \times 10^{6}$ cells are seeded in a T-175 flask).

B. Preparation of different cell suspension in alginate for microencapsulation

1. Remove culture medium from the T-175 flasks, add $5 \mathrm{ml}$ of PBS and remove again to take away remains of culture medium.

2. Add $5 \mathrm{ml}$ of $0.25 \%$ trypsin and keep the flasks in the incubator at $37^{\circ} \mathrm{C}$ for $2-5 \mathrm{~min}$, after which, gently tap the side of the flask to dislodge the cells.

3. Remove cell suspension from the cell culture flask and transfer into a $50 \mathrm{ml}$ conical flask.

4. Filter the cell suspension through a $40 \mu \mathrm{m}$ filter to remove cell aggregations and count the cells with an automatic cell counter or alternatively with a Neubauer Chamber.

5. Collect the volume of cell suspension to get the final cell amount required for cell encapsulation.

6. Spin the collected cell suspension ( $100 \times g$ for $5 \mathrm{~min}$ ) and discard the supernatant carefully.

7. Resuspend cells by adding the needed volume of $1.5 \%$ alginate LVG solution (see Recipes) carefully to get $5 \times 10^{6}$ cells per $\mathrm{ml}$ of alginate density (for a $4 \mathrm{ml}$ batch, $2 \times 10^{7}$ cells are needed).

8. Revolve cell suspension softly using a sterile spatula to homogenize it.

Note: Each cell type is microencapsulated separately in this protocol.

\section{Cells microencapsulation}

1. Transfer the alginate cell suspension into a $10 \mathrm{ml}$ sterile syringe avoiding the formation of bubbles. Place the syringe into a peristaltic pump (Figure 1A) (Video 1).

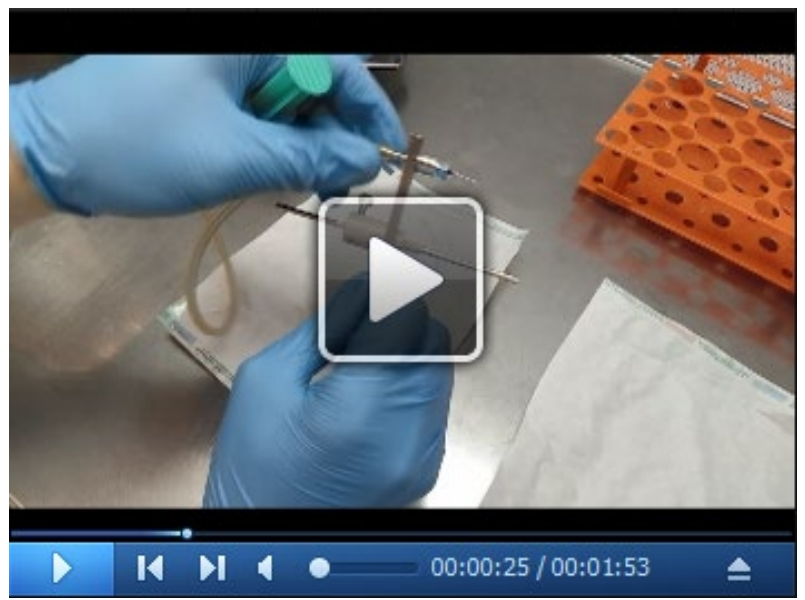

Video 1. Electrostatic droplet generator assembly

Note: All the microencapsulation procedure is performed in a biosafety cabinet. 
2. Connect the syringe to the stainless steel needle tip (inner diameter $0.17 \mathrm{~mm}$ ) with a silicone tube of $40 \mathrm{~cm}$ (Figure 1B).

3. Fill the sterile beaker ( $80 \mathrm{~mm}$ diameter, $40 \mathrm{~mm}$ height and $80 \mathrm{ml}$ volume) containing a small magnetic stirrer with $80 \mathrm{ml}$ of the sterile calcium chloride gelling solution and place it under the needle (see Recipes).

4. Set up magnetic stirring to $200 \mathrm{rpm}$ (this would keep the microcapsules separated during the gelling procedure).

5. For a $380 \mu \mathrm{m}$ diameter microcapsules, place the needle holder at $7 \mathrm{~cm}$ of height (Figure $1 \mathrm{C}$ ), and be sure that the distance between the needle tip and the calcium chloride solution is of $2 \mathrm{~cm}$.
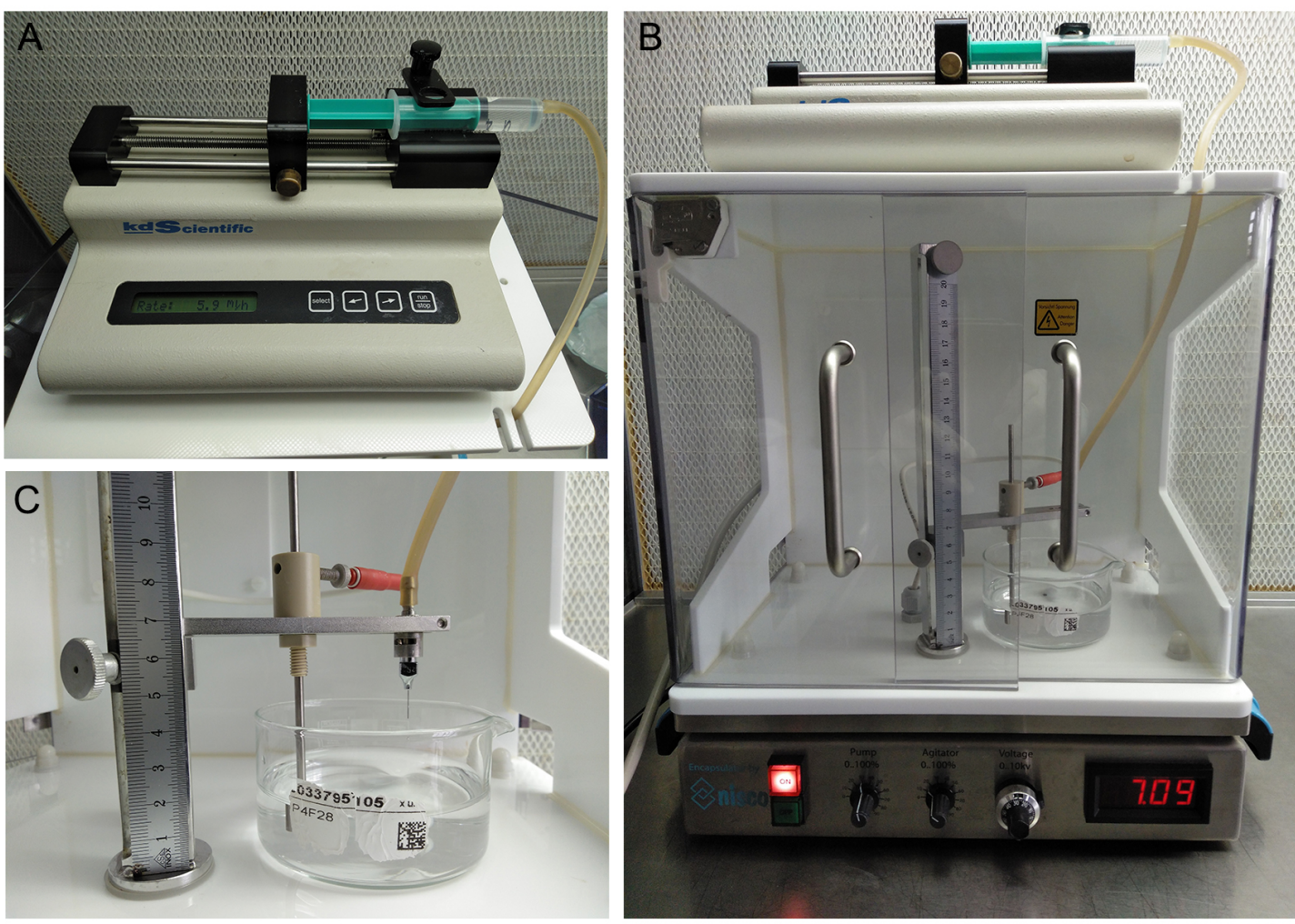

Figure 1. Cell microencapsulation in detail. A. Peristaltic pump set at $5.9 \mathrm{ml} / \mathrm{h}$. B. Complete set-up of the Nisco ${ }^{\circledR}$ microcapsules generator. C. Detail of the set-up of the needle and its holder.

6. Place the stainless steel stick inside the gelling bath and connect the electrode of the microcapsules generator.

7. For $380 \pm 10 \mu \mathrm{m}$ diameter alginate microcapsules, set up the conditions of voltage $(7 \mathrm{kV})$ and flow rate in the peristaltic pump $(5.9 \mathrm{ml} / \mathrm{h})$.

Note: With the described conditions we obtain $380 \pm 10 \mu \mathrm{m}$ diameter alginate microcapsules that will slightly increase in diameter after coating. The bead diameter will decrease with smaller needle diameter and increasing voltage. 
8. Close the electrical safety cage (otherwise the system will not work).

9. Push the syringe manually until the alginate suspension reaches the tip of the nozzle (to take out the air from the silicone tube) and start the peristaltic pump at $5.9 \mathrm{ml} / \mathrm{h}$ speed.

10. Let the alginate solution to be pushed out into the beaker through the nozzle.

11. When the syringe is empty, stop the flow of the pump and let the alginate microcapsules mixing with a magnetic stir at $200 \mathrm{rpm}$ in the calcium chloride solution for at least $10 \mathrm{~min}$ for complete gelation. Collect microcapsules from calcium chloride solution by filtering the solution through a $100 \mu \mathrm{m}$ strainer.

12. Invert the $100 \mu \mathrm{m}$ strainer and place it on the top of a conical tube.

13. Next, collect microcapsules adding $10 \mathrm{ml}$ of complete culture solution to the bottom of the strainer which is upside down.

14. Transfer the microcapsules into a T-75 flask with a pipette and add another $10 \mathrm{ml}$ of complete medium.

15. To confirm microcapsules integrity, shape, and homogeneity, observe them under an inverted microscope by phase contrast. Keep the flask in an incubator at $37{ }^{\circ} \mathrm{C}$ in a humidified $5 \%$ $\mathrm{CO}_{2} / 95 \%$ air atmosphere for further studies (Figure 2).

Note: These microencapsulated cell types can be maintained in culture for at least 2 months.
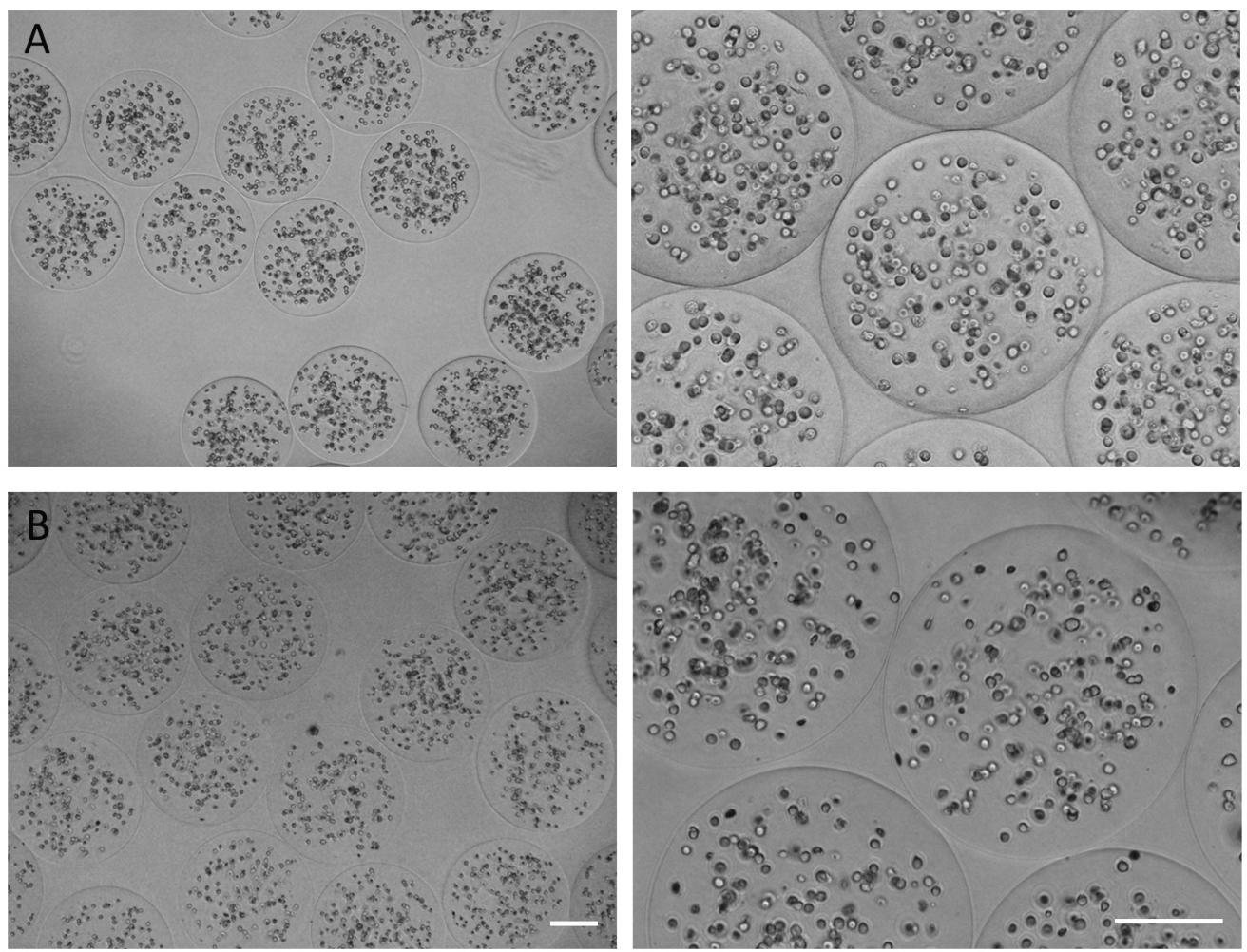

Figure 2. (A) C2C12 and (B) D1MSC cells in alginate microcapsules. Scale bar: $200 \mu \mathrm{m}$.

D. Preparation and conditions for the cryopreservation process

1. Precool the different CPA solutions to $4^{\circ} \mathrm{C}$ (see Recipes). 
2. Precool the CoolCe $\|^{\boxplus}$ container to $4{ }^{\circ} \mathrm{C}$ keeping in a fridge for more than $30 \mathrm{~min}$.

3. Label $2 \mathrm{ml}$ cryovials and let them on ice at $4^{\circ} \mathrm{C}$.

E. Cryopreservation process

1. Collect microcapsules from the T-75 flask and place them into a $1.5 \mathrm{ml}$ Eppendorf tube. Let them sediment by gravity, and repeat this process until $200 \mu \mathrm{l}$ of microcapsules are obtained. Next, remove the medium with a pipette (Figure 3).

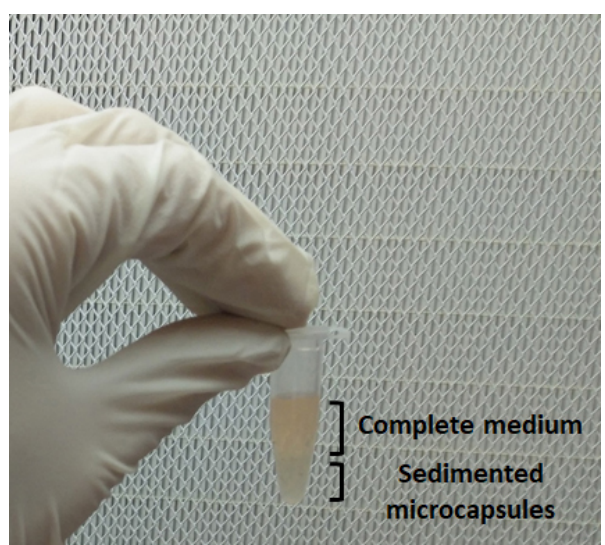

Figure 3. Sedimentation of microcapsules by gravity

2. Add $1 \mathrm{ml}$ of precooled CPA solution to the Eppendorf tubes (see Recipes).

Note: CPA solutions can be prepared fresh, or they can be stored at most for 1 week at $4{ }^{\circ} \mathrm{C}$.

3. Transfer the microcapsules suspension to the $2 \mathrm{ml}$ cryovials and keep them on ice $20 \mathrm{~min}$ (Figure 4).

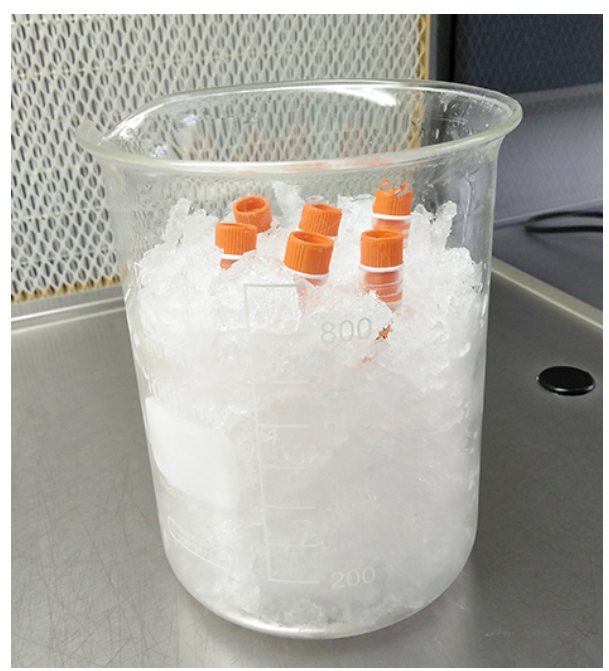

Figure 4. Chilling samples before cryopreservation

4. Transfer the cryovials to the chilled Coolcel ${ }^{\circledR}$ containers. 
5. Introduce the containers in a $-80^{\circ} \mathrm{C}$ freezer for the slow controlled cooling of the samples, and keep them overnight.

6. Next day, take out the Coolcel ${ }^{\circledR}$ container from the $-80{ }^{\circ} \mathrm{C}$ freezer and transfer the cryovials to a liquid nitrogen tank for long-term storage.

F. Microencapsulated cells recovery

1. Carefully take out the cryovials from the liquid nitrogen tank. Transfer them as quick as possible to a $37^{\circ} \mathrm{C}$ water bath for fast thawing.

2. Move them softly in the water bath (3-5 min) trying to avoid the contact of the water with the cryovial lids to avoid contamination risk. On this regard, hold the cryovials from the tips or place them with a polyester holder that avoids tip contact with water.

3. Transfer microcapsules from cryovials into $15 \mathrm{ml}$ conical tubes, and dilute them adding $10 \mathrm{ml}$ of culture medium at room temperature to the $15 \mathrm{ml}$ tube drop by drop. Let the microcapsules to sediment by gravity and then remove the medium. Repeat the process at least twice.

4. Add culture medium at $37{ }^{\circ} \mathrm{C}$ and incubate the microcapsules in a T-75 flask at $37{ }^{\circ} \mathrm{C}$ in a humidified $5 \% \mathrm{CO}_{2} / 95 \%$ air atmosphere.

G. Viability assessment of encapsulated cells under fluorescent microscopy

1. Collect $20 \mu \mathrm{l}$ of microcapsules from the $\mathrm{T}-75$ flask and place it into a $1.5 \mathrm{ml}$ Eppendorf tube. Let sediment by gravity and remove the medium.

2. Rinse the microcapsules three times (letting microcapsules settle by gravity) each with $1 \mathrm{ml}$ of DPBS containing $\mathrm{Ca}^{2+}$ and $\mathrm{Mg}^{2+}$.

3. Dilute rinsed microcapsules with $300 \mu \mathrm{l}$ of calcein/ethidium staining solution for microscopy (see Recipes).

4. Dispense this staining solution containing microcapsules into 3 wells of a 96-well plate (approximately $100 \mu \mathrm{l}$ solution/well).

5. Incubate at room temperature for $\mathbf{4 5}$ min protected from light.

6. Assess under a fluorescent microscope the viability of encapsulated cells (Figure 5). Calcein (excitation $495 \mathrm{~nm}$, emission $515 \mathrm{~nm}$ for viable cells) and ethidium (excitation $495 \mathrm{~nm}$, emission $635 \mathrm{~nm}$ ). The fluorescence from these dyes may be observed separately; calcein with a standard fluorescein bandpass filter and ethidium with filters for propidium iodide or Texas $\operatorname{Red}^{\circledR}$ dye. 
$\mathrm{C} 2 \mathrm{C} 12$
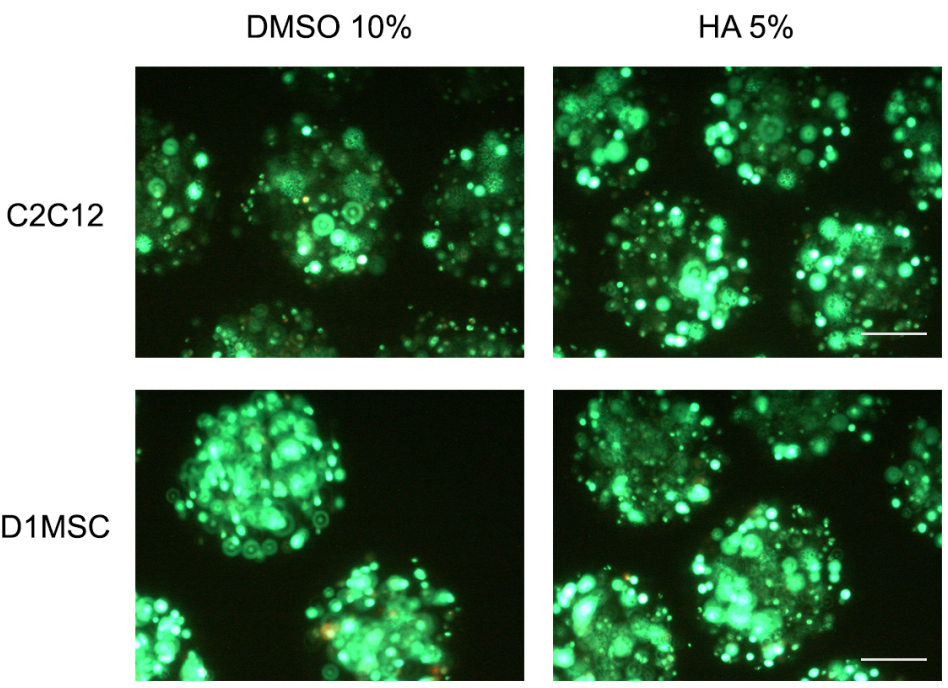

Figure 5. Micrographs of calcein/ethidium stained cryopreserved microencapsulated cells 7 days in culture after thawing. Scale bars: $200 \mu \mathrm{m}$.

H. Determination of the metabolic activity of microencapsulated cells

1. Collect $50 \mu \mathrm{l}$ of microcapsules from the $\mathrm{T}-75$ flask and place it into a $1.5 \mathrm{ml}$ Eppendorf tube and let it sediment by gravity, and next remove the medium.

2. Resuspend the encapsulated cells in $700 \mu \mathrm{l}$ of complete culture medium.

3. Dispense this solution containing the microcapsules into 7 wells of a 96 -well plate $(100 \mu \mathrm{l}$ solution/well). Also, dispense $100 \mu \mathrm{l}$ of just complete culture medium into 2 wells (negative control).

4. Add $10 \mu \mathrm{l}$ of solution for viability quantification (CCK-8) into each well.

5. Incubate the 96 well-plate inside a wet chamber on an incubator for $4 \mathrm{~h}$ at $37^{\circ} \mathrm{C}$.

6. After $4 \mathrm{~h}$, transfer the supernatants into another 96-well plate.

7. Measure the absorbance at $450 \mathrm{~nm}$ with reference wavelength at $650 \mathrm{~nm}$ using Infinite ${ }^{\circledR} \mathrm{M} 200$ microplate reader or another microplate reader (Figure 6).

A

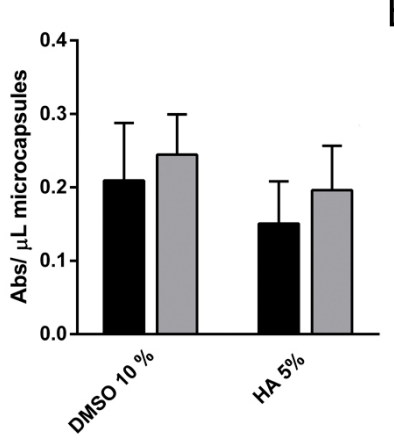

B

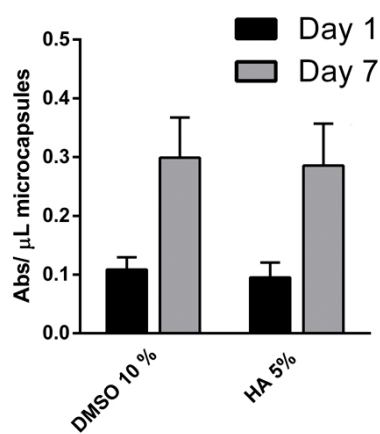

Figure 6. Metabolic activity of cryopreserved microencapsulated (A) C2C12 and (B) D1MSC cells on Days 1 and 7 after thawing 
I. Viability quantification of microencapsulated cells by flow cytometry

1. Collect $100 \mu \mathrm{l}$ of microcapsule, corresponding to $5 \times 10^{5}$ cells, from the T-75 flask and place it into a $1.5 \mathrm{ml}$ Eppendorf tube and let it sediment by gravity, remove next to the medium.

2. Rinse twice the microcapsules with DPBS.

3. Remove the supernatant and add $100 \mu \mathrm{l}$ of $1 \%$ sodium citrate (see Recipes). Pipette up and down until microcapsules are dissolved.

4. Filter the sample through a $40 \mu \mathrm{m}$ cell strainer into different $15 \mathrm{ml}$ conical tubes.

5. Centrifuge the tubes at $100 \times \mathrm{g}$ for $10 \mathrm{~min}$ and discard the supernatant to remove the rests of alginate.

6. Add the staining solution ( $1 \mathrm{ml}$ for each sample) and incubate them for $20 \mathrm{~min}$ protected from light (see Recipes). Control samples are needed for cytometer calibrating (one without dyes, other with calcein and another one with ethidium).

7. Transfer samples to $5 \mathrm{ml}$ round bottom tubes to quantify cell viability in the FACS Calibur flow cytometer $^{\mathrm{TM}}$ (Figure 7).

A

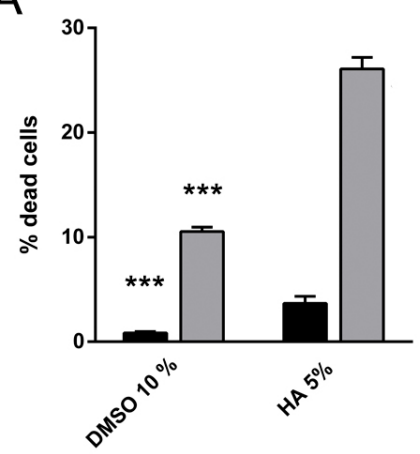

B

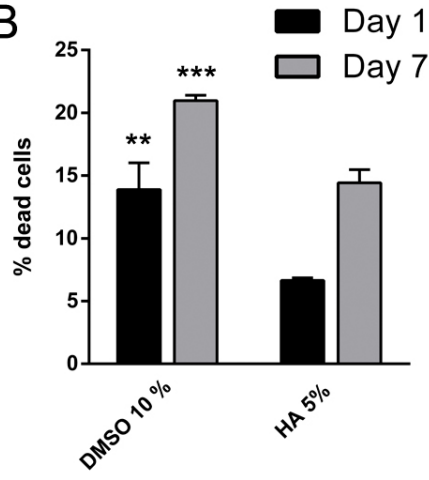

Figure 7. Quantification of dead cells in cryopreserved microencapsulated (A) C2C12 and (B) D1MSC cells on Days 1 and 7 after thawing. Values represent mean \pm SD. ${ }^{* *}: P<$ 0.01 and $^{* * *}: P<0.001$ compared to HA $5 \%$.

\section{Data analysis}

All quantifications are conducted in triplicates, with at least three independent experiments. The mean and standard deviation are calculated by functions 'AVERAGE' and 'STDEV' respectively in Microsoft Office Excel, and the statistical analysis are performed with SPSS software. Cytometer data analysis is performed with FlowJo ${ }^{\circledR}$ V10 (Flowjo, LLC). Microscope micrographs are analyzed with Eclipse Net software, version 1.20.0.

The metabolic activity values increased as expected from Day 1 to Day 7 in each cryopreserved microencapsulated cell type independently of the CPA used due to cell proliferation within microcapsules (Figure 6). Moreover, dead cells percentages increased from Day 1 to Day 7 in each cryopreserved microencapsulated cell type independently of the CPA used (Figure 7). The increase 
in dead cell percentage can be explained with the cryopreservation-induced onset cell death phenomena, as cell death values are increased after $24 \mathrm{~h}$ of thawing.

\section{$\underline{\text { Recipes }}$}

1. D1MSC complete medium

From $500 \mathrm{ml}$ DMEM (ATCC) bottle remove 10\% of volume and add $1 \%$ volume of antibiotic/antimycotic solution, and add $10 \%$ volume of the FBS

2. $\mathrm{C} 2 \mathrm{C} 12$ complete medium

From $500 \mathrm{ml}$ DMEM (Gibco) bottle remove 10\% of volume and add $1 \%$ volume of antibiotic/antimycotic solution, and $10 \%$ volume of the FBS

3. DMSO 10\% CPA solution

Add $1 \mathrm{ml}$ of DMSO in $9 \mathrm{ml}$ of each complete cell culture medium and store it at $4{ }^{\circ} \mathrm{C}$

4. LMW-HA 5\% CPA solution $(20 \mathrm{ml})$

a. Resuspend $200 \mathrm{mg}$ LMW-HA powder in $10 \mathrm{ml}$ of complete medium and stir until is dissolved under aseptic conditions

b. When dissolved add $10 \mathrm{ml}$ of complete medium and store it at $4{ }^{\circ} \mathrm{C}$

5. $1 \%$ mannitol

a. Dissolve $1 \mathrm{~g}$ of mannitol into $100 \mathrm{ml}$ of distilled water or scale up to the required volume

b. Stir until mannitol gets dissolved and filter through a Millipore $0.22 \mu \mathrm{m}$ filter Stericup ${ }^{\circledR}$

6. $55 \mathrm{mM}$ calcium chloride $(500 \mathrm{ml})$

a. Dissolve $2.44 \mathrm{~g}$ of calcium chloride ( $96 \%$ purity) into $500 \mathrm{ml}$ of $1 \%$ mannitol solution

b. Scale up the amounts of calcium chloride to higher volumes

c. Stir until it dissolves, and filter through a Millipore $0.22 \mu \mathrm{m}$ filter Stericup ${ }^{\circledR}$

7. $1 \%$ sodium citrate

a. Dissolve $1 \mathrm{~g}$ of sodium citrate into $100 \mathrm{ml}$ of $1 \%$ mannitol or scale up to the required volume

b. Stir until it gets dissolved and filter through a Millipore $0.22 \mu \mathrm{m}$ filter Stericup ${ }^{\circledR}$

8. $1.5 \%$ alginate LVG (NovaMatrix)

a. Dissolve $1.5 \mathrm{~g}$ alginate into $100 \mathrm{ml}$ of $1 \%$ mannitol and stir

b. When alginate solution is transparent, filter through a $0.20 \mu \mathrm{m}$ syringe filter

Note: For higher volumes of alginate solution, scale up as required. Lower or higher alginate concentrations will require you to modify the weight of alginate dissolved into $1 \%$ mannitol. We recommend filtering on steps of $2 \mathrm{ml}$ since higher alginate volumes require strength to get filtered due to its high viscosity.

9. Calcein/ethidium staining solution (for microscopy)

Dilute $5 \mu \mathrm{l}$ of ethidium and $5 \mu \mathrm{l}$ of calcein provided in the LIVE/DEAD ${ }^{\circledR}$ Viability/Cytotoxicity Kit for mammalian cells (Life-Technologies) into $10 \mathrm{ml}$ of DPBS containing $\mathrm{Ca}^{2+}$ and $\mathrm{Mg}^{2+}$

10. Calcein/ethidium staining solution (for flow cytometry) 
a. Prepare a calcein stock of $100 \mu \mathrm{M}$ solution diluting $4 \mu \mathrm{l}$ of calcein provided in the LIVE/DEAD ${ }^{\circledR}$ Viability/Cytotoxicity Kit for mammalian cells (Life-Technologies) in $156 \mu$ l of DMSO

b. For control with only calcein, add $2 \mu \mathrm{l}$ of calcein stock in $1 \mathrm{ml}$ of cell culture medium

c. For control with only ethidium, add $4 \mu \mathrm{l}$ of ethidium provided in the LIVE/DEAD ${ }^{\circledR}$ Viability/Cytotoxicity Kit in $1 \mathrm{ml}$ of cell culture medium

d. For each sample, add $2 \mu \mathrm{l}$ of calcein stock and add $4 \mu \mathrm{l}$ of ethidium in $1 \mathrm{ml}$ of cell culture medium

Note: Use cell culture medium of each cell type without serum and Antibiotic/antimycotic.

\section{Acknowledgments}

This protocol was adapted from the previously published study (Murua et al., 2009) and (Gurruchaga, et al., 2015a) Author thanks the University of the Basque Country (UPV/EHU) for granted fellowship. Authors also wish to thank the intellectual and technical assistance from the ICTS "NANBIOSIS", more specifically by the Drug Formulation Unit (U10) of the CIBER-BBN at the UPV/EHU.

\section{Competing interests}

The authors have no relevant affiliations or financial involvement with any organization or entity with a financial interest in or financial conflict with the subject matter or materials discussed in the manuscript. This includes employment, consultancies, honoraria, stock ownership or options, expert testimony, grants or patents received or pending, or royalties.

\section{$\underline{\text { References }}$}

1. Gryshkov, O., Hofmann, N., Lauterboeck, L., Pogozhykh, D., Mueller, T. and Glasmacher, B. (2015). Multipotent stromal cells derived from common marmoset Callithrix jacchus within alginate 3D environment: Effect of cryopreservation procedures. Cryobiology 71(1): 103-111.

2. Gurruchaga, H., Ciriza, J., Saenz Del Burgo, L., Rodriguez-Madoz, J. R., Santos, E., Prosper, F., Hernandez, R. M., Orive, G. and Pedraz, J. L. (2015a). Cryopreservation of microencapsulated murine mesenchymal stem cells genetically engineered to secrete erythropoietin. Int J Pharm 485(1-2): 15-24.

3. Gurruchaga, H., Saenz del Burgo, L., Ciriza, J., Orive, G., Hernandez, R. M. and Pedraz, J. L. (2015b). Advances in cell encapsulation technology and its application in drug delivery. Expert Opin Drug Deliv 12(8): 1251-1267.

4. Hutson, E. L., Coleman, C.M., Freestone, S. F., Huckle, J., Murphy, M. and Barry, F. (2009). Hyaluronic acid as a cryopreservant of mesenchymal stem cells. 55th Annual Meeting of the 
Orthopaedic Research Society.

5. Iwama, A., Yamada, C., Uchida, K. and Ujihira, M. (2014). Pre-incubation with hyaluronan reduces cellular damage after cryopreservation in densely cultured cell monolayers. Biomed Mater Eng 24(2): 1497-1506.

6. Mantri, S., Kanungo, S. and Mohapatra, P. C. (2015). Cryoprotective effect of disaccharides on cord blood stem cells with minimal use of DMSO. Indian J Hematol Blood Transfus 31(2): 206-212.

7. Massie, I., Selden, C., Morris, J., Hodgson, H. and Fuller, B. (2011). Cryopreservation of encapsulated liver spheroids using a cryogen-free cooler: high functional recovery using a multi-step cooling profile. Cryo Letters 32(2): 158-165.

8. Murua, A., Orive, G., Hernandez, R. M. and Pedraz, J. L. (2009). Cryopreservation based on freezing protocols for the long-term storage of microencapsulated myoblasts. Biomaterials 30(20): 3495-3501.

9. Orive, G., Santos, E., Pedraz, J. L. and Hernandez, R. M. (2014). Application of cell encapsulation for controlled delivery of biological therapeutics. Adv Drug Deliv Rev 67-68: 3-14.

10. Ruiz-Delgado GJ, Mancías-Guerra C, Tamez-Gómez EL, Rodríguez-Romo LN, López-Otero A, Hernández-Arizpe A, Gómez-Almaguer D, Ruiz-Argüelles GJ. (2009). Dimethyl sulfoxide-induced toxicity in cord blood stem cell transplantation: report of three cases and review of the literature. Acta Haematol 122(1):1-5.

11. Shu, Z., Heimfeld, S. and Gao, D. (2014). Hematopoietic SCT with cryopreserved grafts: adverse reactions after transplantation and cryoprotectant removal before infusion. Bone Marrow Transplant 49(4): 469-476.

12. Ujihira, M., Iwama, A., Aoki, M., Aoki, K., Omaki, S., Goto, E. and Mabuchi, K. (2010). Cryoprotective effect of low-molecular-weight hyaluronan on human dermal fibroblast monolayers. Cryo Letters 31(2): 101-111. 